\title{
CROPS FOR CANNING AND DEEP FREEZING
}

L. R. RENOUF, Field Supervisor, J. Wattie Canneries, Gisborne

Since the early 1940 s there has been an appreciable change in the production of food crops: from the intensified methods of market gardening on fairly small holdings supplying the crops fresh to market, to large-scale production of these crops for processing for canning and deep freezing.

In the last ten years there has been a steady increase in the areas grown for processing.

Official figures show that in 1950 a total of 15,300 acres of vegetable crops were grown in New Zealand and this includes those grown to supply the produce fresh to markets as well as those supplied for processing. In 1954, 10,000 acres were grown for processing alone and in 1959 the area had reached a total of 15,000 acres of crops grown for processing.

Of New Zealand's total area of crops for processing, between 10 per cent and 12 per cent has been grown in Gisborne, where processing has been in operation since the 1951-52 season, and production from these areas has compared very favourably with that in any other parts of the country. Also experience has shown that when due consideration has been given to the soil types, levels of properties, and cultural methods, the production of crops for processing here is a sound economic proposition. are:

Crops grown for this purpose in Gisborne and planting periods

Peas-mid-August to mid-November.

Sweet corn-mid-October to mid-December.

Tomatoes-mid-October to early November.

Green beans-end October to late November.

Spinach-end August.

Asparagus.

Golden Queen peaches.

Trials with other crops are being carried out.

The area of processing crops will increase in Gisborne as the local and present overseas markets expand and new markets are opened up, and while it is not possible to forsee to what extent increases will take place with the main vegetable crops, it is planned to develop peach growing here to the extent of 200 acres in the next four years.

\section{Areas and Soils}

A survey of the areas between the hills around Gisborne has 
shown that there is approximately 40,000 acres of flat ground.

After considering all the factors that must be taken into account, which will be dealt with later, in the selection of suitable areas for processing crops, it is assessed that from 10,000 to 11,000 acres would be the total from which good production of the main vegetable crops could be relied on year by year.

Of this area it is estimated that not more than 1,000 acres would be ideally suited for the growing of very early crops and of peaches and asparagus, which require a good depth of friable, well drained soil that will not remain saturated to a depth of $1 \mathrm{ft} .6$ in. at least, even in the wettest periods.

It is doubtful if any other area in New Zealand used for growing horticultural crops has soil types comparable in make-up and variation to those of the Gisborne flats.

There is considerable variation in types on individual farms and in individual paddocks and to obtain the spread planting and even maturity of mechanically harvested crops so essential to processors, much thought has to be given to the selection of the right types for the right planting period.

Apart from the very recent and saline soils, other types have proved to be highly fertile when favourable conditions such as moderate rainfall and lack of long dry periods are experienced.

Analysis of results of production shows that under these conditions there is little to choose between soil types, but it has been found that the periods over which they can be used for successful cropping vary considerably. Also there is great variation in the extent to which the different types withstand adverse conditions.

The major factors governing the usage of the different soil types are: drainage; unevenness of surface; and difficulty of working the soil.

Apart from Matawhero and Waihirere silt loams, which are well drained and can be utilised from August onwards, very slow movement of water takes place in the other types and it is not possible to use these until September, October, and even into November.

On many of the heavier soils the surface becomes sealed very quickly in wet weather and causes water to lie even though the topsoil is free of excess moisture.

In parts of the district insufficient major drains cause otherwise well drained paddocks to remain wet for long periods through water backing up from the drains. This has been very obvious this season when just on 7 in. of rain fell in October.

The worth of paddocks near hills is governed by hill seepage in wet seasons.

The use of heavy harvesting equipment in wet conditions, poaching by stock, and the breaking down of soil structure by 
excessive cropping have in many cases aggravated poor drainage.

Marked undulations ranging from small depressions to old stream beds occur over a large area of the plains on both light and heavy soils. These undulations carry water very late after wet winters, and though they comprise only a small part of individual paddocks, they govern their usage. Instances have been noted of well-drained paddocks having only 3 per cent to 5 per cent of their area in depressions being up to four weeks later than level paddocks with similar soil types.

Production from these depressions. even in seasons of favourable conditions after planting of crops has always been poor and in wet seasons losses of crops have been- frequent. The wet areas in spring and early summer have been found to be the driest in late summer, and mixed maturity in pea and corn crops has caused loss of production due to having to judge the harvesting by the most forward parts of the crops.

This feature of unevenness of surfaces is probably the most important in governing the usage of soils for cropping and is particularly so in respect to the large areas of the friable phases of the Waihirere soils, which in other respects are as good as any soils in the district.

With the exception of Matawhero and Waihirere silt loams, the soils must be regarded as difficult to work for cropping.

While the heavier soils are readily worked from turf, they are more difficult to cultivate after cropping and become progressively worse as cropping is continued.

Even after two to three years of cropping the structure of many of the soils breaks down and it becomes extremely difficult to obtain a suitable tilth for processing crops.

Strong winds are general in late September, October, and November, and the wet soil exposed when cultivating under these conditions is often dried out in a matter of hours and large clods can then only be battered down to smaller clods, not to the fine tilth required. Quick drying out is aggravated by the apparent ability of the soils to absorb heat very rapidly. These characteristics play a very large part in limiting the use of soils for the requirements of the factory.

Other features that have to be considered in selecting areas to produce high yields are: extensive cracking of soils that occurs in dry seasons, particularly in the Makauri, Kaiti, and Makaraka series, and the incidence of diseases in peas and sweet corn when these crops are grown on the more recent Waipaoa type.

After seven years' experience (the first few of which were very hard ones, due mainly to lack of knowledge of the features mentioned) of cropping on the flats up to a distance of 16 miles from Gisborne, approximately 85 per cent of the total processing crops 
are now being grown on the Matawhero, Waihirere, and Makaraka soil types and the balance spread between the Kaiti, Waipaoa, and Makauri types.

That the growing of crops for processing in Gisborne is a sound economic proposition is borne out by the following production figures (the average over the past five years and the peak of each crop during this time):

$\begin{array}{lccccc} & & & & \text { Tons per acre } & \text { Tons per acre } \\ \text { Sweet corn } & & & & 4.57 & 7.75 \\ \text { Peas } & & & & 1.4 & 1.87^{*} \\ \text { Tomatoes _...- } & & & 14.8 & 22.25 \\ \text { Dwarf beans } & & & 3.9 & \mathbf{6 . 2 3}\end{array}$

*High quality freezing peas.

Note that peak production of all these crops has come from Matawhero soil types.

The over-all average of these crops has improved over the past three years, due to the added knowledge gained of soil conditions; vastly improved cultural methods; improvements in weed sprays and technique in the application of these; and improved selection of varieties of each crop.

Golden Queen peaches and asparagus are in the early stages of development, but very promising production has been obtained. Five-year-old peach trees have produced 7 tons per acre and $1 \frac{1}{8}$ tons of asparagus has been achieved. Prospects of considerably higher yields from both these crops as they develop are good.

\section{0 ther $F$ actors $\mathrm{G}$ overning Production}

Many points come to light every year in either dry or wet conditions.

First is that the highest production has come from cropping on paddocks cultivated from old pastures. There has been little difference between first and second crops, but production has decreased noticeably after the second crop in most cases.

Apart from obtaining very high yields by cropping for only two years and regrassing, the fertility of the soil is maintained at a high level, resulting in greatly increased stock carrying capacity. Also two years' cropping is an efficient means of eradicating bad weeds such as barley grass, Japanese grass, and Californian thistle from pastures.

Pea crops grown on ground up to two years from grass have produced 15 to 20 per cent higher average crops than those grown in older ground, while sweet corn crops have shown an even more appreciable difference, production having been from 20 to 30 per cent higher on new ground.

Sweet corn, as well as the other processing crops, is an entirely different and much more tender crop to grow than maize, which 
is the main crop grown in the district. Maize will produce good yields for a fairly long period in one paddock, but the longer it is grown the poorer the condition of the soil will become and the longer it will take to rejuvenate to be satisfactory for the growing of processing crops.

Beans produce well for two years in ground from grass, but production in older ground has been very low indeed.

High production of tomatoes has come only from the newer ground and with this crop the policy has been to grow for only one year in any one paddock and to maintain not less than a four-year cycle to avoid build up of diseases.

Some improvement to older soils have been made with shortterm cover crops such as cereals, but improvements have been of a temporary nature and sometimes, particularly with barley, of a detrimental nature in the way this cropping has been carried out.

Obtaining the full benefit of cover crops such as barley, oats, and mustard means the loss of stock carrying capacity during the winter. By grazing off these crops some returns are gained with stock, but it is doubtful if this type of cropping is sufficient to warrant the expense involved for the benefit gained. None of these crops will do what grass and the stock that go with it will do.

The most beneficial winter crop has been grass. The planting, after crops have been harvested, of short rotation ryegrass, which produces heavily in winter and will allow fairly heavy stocking in this period, has given as good results as any crop.

Where farmers rely on perennial grass seed crops the question of fouling the paddocks can be overcome by running the first round of the drill with perennial and the balance in short-rotation ryegrass. As under these condition the short-rotation would be grazed off and not allowed to seed, and after ploughing the only grass left around the verges would be perennial, there is little likelihood of perennial seed growers getting into difficulties.

Early working of ground is essential to obtain maximum production. With combined stock and cropping farms there are times when stock is held late and ground is worked within a few weeks of planting. In these cases more money may be made from stock, but less will be made from the resultant crops. All really high production has come from ground worked at least six weeks before planting. Even in this time grass paddocks should be top worked before ploughing.

Weed control sprays efficiently applied at the correct times on pea and sweet corn crops will greatly assist in obtaining high production, but crops can be materially affected by faulty application.

In pea crops D.N.B.P. sprays, preferably applied when plants are 4 in. to 6 in. high, will give good weed control. Faulty appli- 
cation will mean respraying later, which causes damage and losses in crops.

Weeds in sweet corn crops can be successfully controlled with the use of the amine salts of 24D when the plants are 4 in. to 6 in. high. Spraying later than this causes distortion and damage to crops and this becomes progressively worse the later the spray is applied.

Another feature that has materially affected production in many parts of the district is the overgrown plantations or shelter belts, which in a number of instances have been responsible for complete losses of 5 per cent to 15 per cent of crops grown in paddocks adjoining the trees. Losses of this nature are very costly when it is considered that the land referred to is valued at $£ 200$ to $£ 300$ per acre and also that the trees are of little value for any purpose.

Fertilisers applied to older paddocks have improved production, but little response has been observed when applications have been made to paddocks from grass. The application of 2 to $3 \mathrm{cwt}$ of superphosphate to pea crops and 3 to $4 \mathrm{cwt}$ of blood and bone or 1 to 2 cwt of sulphate ammonia to corn and bean crops has given improved results when it has been necessary to grow these crops in old ground.

With the increasing land values and corresponding high rates and with general working costs high, it is vital to give full consideration to all the points mentioned to maintain and even increase production to keep the growing of these crops on a sound economic basis.

The main features where improvements can be made and land usage increased can be summed up as follows:

Improved drainage facilities.

Levelling of undulations where soil depth allows.

The use of subsoilers to obviate packing that has occurred over the years.

The removal of useless trees and trimming back of useful stock shelter.

Greater consideration to shorter term cropping and rotating with grass and stock.

More thought to earlier working of ground.

High crop yields are the main aim of the growers, but while the processor also aims to this end, quality is the most vital factor to him, and quality produce can come only from crops grown under the best conditions and given the best attention.

Experience has shown that to achieve our aims of quantity plus quality the most practical approach is to plan a balanced level of rotational cropping with stock farming. 